\title{
INTEGRALISME ILMU DALAM ISLAM (SEJARAH PERKEMBANGAN DAN KLASIFIKASI)
}

\author{
Iis Uun Fardiana 1
}

\begin{abstract}
Abstact: One method in the process of Islamic knowledge is integralization. While integralism sees that integralization is the integration of the richness of human knowledge with revelation (Allah's guidance in the Qur'an and its implementation in the Sunnah of the Prophet). Integralistic science is the science that unites (not merely combines) God's revelation and the discovery of the human mind. The integralistic sciences will not exclude God (secularism) or exclude humans (other worldly asceticism). It is hoped that integralism will simultaneously resolve the conflict between extreme secularism and radical religions in many sectors. The idea of Islamization of science emerged as a response to the dichotomy between the science of religion and science which entered the secular West and the culture of modern society into the Islamic world. The progress that modern science has made has a remarkable effect, but on the other hand it also has a negative impact, because modern science (West) is dry value apart from religious values. In addition, Islamization of Science is also a reaction to the crisis of educational system faced by Muslims, namely the dualism of Islamic education system and modern education (secular) that confuses Muslims.
\end{abstract}

Keyword: Integration, Science, Islam

\footnotetext{
1 DOSEN TETAP TARBIYAH IAI SUNAN GIRI PONOROGO
} 


\section{PENDAHULUAN}

Dikotomi ilmu pengetahuan adalah masalah yang selalu diperdebatkan dalam dunia Islam, mulai zaman kemunduran Islam sampai sekarang. Islam menganggap ilmu pengetahuan sebagai konsep yang holistis. Di dalam konsep ini tidak terdapat pemisahan antara pengetahuan dengan nilai-nilai.

Selanjutnya jika dikaji lebih lanjut bagaimana Islam memandang ilmu pengetahuan maka akan ditemui bahwa Islam mengembalikan kepada fitrah manusia tentang mencari ilmu pengetahuan. Dalam Al-Qur'an banyak ditemukan ayat yang menjelaskan tentang sains, dan mengajak umat Islam untuk mempelajarinya. Tidak diragukan lagi bahwa Al-Qur'an adalah sumber ilmu pengetahuan . al-Qur'an diturunkan bagi manusia sebagai pedoman bagi manusia dan petunjuk dalam menganalisis setiap kejadan di alam ini yang merupakan inspirasi terhadap perkembangan ilmu pengetahuan.

Secara historis dapat diketahui bahwa dunia Islam pernah menggapai kejayaan dan kemegahan yang ditandai dengan maraknya ilmu pengetahuan dan filsafat, sehingga menjadi mercusuar baik di Barat maupun di Timur. Pada abad pertengahan, telah bermunculan para saintis dan filsuf caliber dunia di berbagai lapangan keilmuan. Dalam bidang fikih terdapat Imam Malik, Imam Syafi'I, Imam Hambali, Imam Abu Hanifah, dalam bidang filsafat muncul AlKindi, Al-Farabi, dan Ibnu Sina, sedang dalam bidang sains muncul Ibnu Hayyan, Al-Khawarizmi dan Al-Razi.2 Para filsuf dan saintis muslim tersebut tidak pernah ilmu pengetahuan dan agama. Mereka meyakini ilmu pengetahuan dan agama sebagai suatu totalitas dan integralitas Islam yang tidak dapat dipisahkan satu dengan yang lainnya.

Namun, nampaknya masih ada anggapan yang sangat kuat dimasyarakat muslim bahwa "agama" dan "ilmu" adalah dua hal yang tidak bisa "dijodohkan", karena dianggap masing-masing punya sumber yang berbeda, di mana agama berasal dari wahyu Ilahi yang suci dan abadi, sehingga pengamalan agama lebih diutamakan karena menjadi penentu di kehidupan ukhrawi. Sedangkan ilmu pengetahuan berasal dari

2

Harun Nasution, Pembaruan dalam Islam, (Jakarta: Bulan Bintang, 1975), h.13. 
penalaran akal, yang kedudukannya lebih rendah dari wahyu, sehingga menguasainya adalah kefanaan. Singkatnya, meminjam bahasa Amin Abdullah (2003:3), "ilmu tidak mempedulikan agama dan agama tidak mempedulikan ilmu". Padahal kalau diperhatikan dua "sejoli" tersebut sangat serasi, karena keduanya tidak "sejenis"

Di lain pihak, ilmu yang berkembang di Barat adalah ilmu sekuler, dan inilah yang menjalar di tengah-tengah ilmuwan muslim. Menjalarnya ilmu Barat di tengah-tengah ilmuwan muslim ini mengarah pada sekuralisasi. Sekuralisasi ini menyebabkan berpisahnya ilmu pengetahuan modern dari nilainiai spiritual, yang menyebabkan kemerosotan kehidupan beragama.

"Perceraian" ini bisa dilihat implikasinya terhadap model pendidikan. Di satu pihak ada pendidikan yang memperdalam ilmu pengetahuan modern saja yang kering dari nilai-nilai keagamaan, dan sisi lain ada pendidikan yang hanya memperdalam masalah agama yang terpisahkan dari perkembangan ilmu pengetahuan.

Kenyatan inilah yang melahirkan gagasan yang dilakukan oleh para pemikir Islam seperti Naquib Al-Atthas dan Ismail Raji Al-Faruqi untuk "menjodohkan" kembali ilmu umum dan ilmu keislaman. Istilah yang populer dalam konteks integrasi ini adalah Islamisasi. Hal ini dilatarbelakangi kekecewaan terhadap sistem pendidikan yang diterapkan di dunia Islam yang dinilai telah mempraktekan dualisme pendidikan, di mana praktek dualisme ini sebenarnya dikarenakan kemunduran umat Islam dalam segala bidang, sering dengan kemajuan Barat yang menguasai berbagai bidang, ilmu pengetahuan dan berusaha menguak misteri alam dengan menaklukan lautan dan daratan.

Dalam makalah ini, penulis dengan kapasitasnya mencoba menggambarkan bagaimana antara masing-masing pandangan di atas berimplikasi terhadap perkembangan ilmu itu sendiri. Pada pembahasan pertama, akan diuraikan bagaimana dikotomi ilmu pengetahuan dalam peradaban Islam, kemudian dilanjutkan pada kedua, mengenai islamisasi sains, dan ketiga digambarkan tentang integralisme Islam dengan mengutip dari Armahedi Mahzar, dan pada pembahasan terakhir, tentang paradigma integrasi ilmu masa depan. 


\section{PEMBAHASAN \\ Dikotomi Agama dan Sains}

Dikotomisasi pada hakikatnya merupakan upaya pembagian atas dua konsep yang saling bertentangan. Dikotomisasi pengetahuan ini muncul bersamaan atau beriringan dengan masa renaissance di Barat. Sebelumnya, kondisi sosio-religius maupun sosio-intelektual di Barat dikendalikan gereja. Ajaran- ajaran kristen dilembagakan dan menjadi penentu kebenaran ilmiah. Semua temuan ilmiah bisa dianggap sah dan benar bila sesuai dengan doktrindoktrin gereja. Sebaliknya, bila temuan -temuan ilmiah yang tidak sesuai atau bertentangan dengan doktrin tersebut harus dibatalkan demi supremasi gereja. Maka tidak jarang kemudian, banyak para ilmuwan yang tetap mempertahankan kebenarannya, menjadi korban kekejaman gereja. Untuk merespon hal tersebut, para ilmuwan mengadakan koalisi dengan raja untuk menumbangkan kekuasaan gereja. Usaha tersebut berhasil dan tumbanglah kekuasaan gereja, kemudian muncul Renaissance. Masa Renaissance ini melahirkan sekulerisasi (pemisahan urusan dunia dan akhirat) dan dari sekulerisasi ini lahirlah dikotomisasi pengetahuan.3

Salah satu persoalan serius yang masih menghantui masyarakat Islam hingga kini adalah persoalan "perceraian" antara agama dan ilmu pengetahuan (sains) ini. Berbeda dengan di Barat di mana dikotomi terjadi karena ketidak sesuaian temuan-temuan sains dengan ajaran agama mereka-dalam hal ini adalah Kristen-, sedangkan dalam masyarakat Islam adalah masih kuatnya anggapan bahwa mencari ilmu agama adalah fardhu 'ain, sedangkan sains hanya fardhu kifayah, di mana tidak wajib bagi setiap individu muslim untuk menuntutnya, menambah sederetan problem rumit yang menyebabkab pendidikan Islam semakin terkebelakang.

Anggapan tersebut pada realitasnya telah membawa dampak negatif dalam perkembangan Islam. Banyak orang-orang muslim lebih mengedepankan ilmuilmu agama daripada ilmu-ilmu umum. Mereka belum dapat bersikap "mesra" dan "mengharmonis"-kan antara agama dan ilmu pengetahuan. Akibatnya yang dlahirkan hanya umat muslim

\footnotetext{
3 Mujamil Qomar, Epistemologis Pendidikan Islam: dari Metode Rasional hingga Metode Kritik, (Jakarta, Erlangga, 2005), h. 74-75.
} 
yang bisanya tahlilan dan maulidan. Atau mereka yang setiap melakukan suatu aktifitas harus mencari ayat atau hadits yang mendukung atau melarang kegiatan mereka, yang berpotensi menimbulkan perdebatan yang hanya berenang -renang antara kata "boleh" atau "tidak", yang ujung-ujungnya kedua kata tersebut bisa dikerjakan, tergantung persepsi masing-masing. Hal seperti ini yang membuat umat Islam stagnan, di mana ketika umat Islam berdebat sengit tentang penetapan awal bulan Ramadhan, Barat sudah menapakkan kakinya di bulan. Ketika Barat sudah menciptakan bom atom, umat Islam baru bisa membuat kacang atom.

Fazlur Rahman dalam bukunya Islam and Modernity, Transformation of an Intellectual Tradition telah menunjukkan secara gamblang sebab-sebab kemunduran umat Islam sebagai berikut:

1. Ada pandangan yang terus menerus diungkapkan, yaitu bahwa karena ilmu itu luas dan hidup ini singkat, maka orang harus memberikan prioritas, dan prioritas tersebut dengan sendirinya diberikan kepada sains-sains agama, yang merupakan kunci kejayaan hidup di akhirat.

2. Penyebaran sufisme, yang - demi untuk menumbuhkan kehidupan spiritual intern dan pengalaman keagamaan yang langsung- pada umumnya bersikap memusuhi sains-sains rasional dan juga seluruh intelektualisme.

3. Kemerosotan gradual sains dan filsafat adalah, tentu saja, bahwa sementara pemegang-pemegang ijazah sains-sains keagamaan bisa memperoleh pekerjaan sebagai qadhi atau mufti, sebagai seorang filsuf atau santis hanya tersedia lowongan kerja di istana saja.

4. Sikap tokoh-tokoh keagamaan penting yang istimewa seperti Al-Ghazali yang tidak saja menentang sains an sich tapi juga filsafat sebagaimana yang dikemukakan filosof-filosof Muslim besar seperti Al-Farabi dan khususnya Ibnu Sina. Mereka dituduh sebagai ahli bid'ah.4

Kritik Fazlur Rahman terhadap Al-Ghazali disebabkan pengklasifikasian ilmu ke dalam ilmu-ilmu religius dan ilmu-ilmu

\footnotetext{
4 Syamsul Ma'arif, Revitalisasi Pendidikan Islam, (Yogyakarta: Graha Ilmu, 2007), h.27-28.
} 
intelektual oleh Al-Ghazali, sehingga para sarjana muslim mengabaikan ilmuilmu intelektual karena dianggap sebagai ilmu yang tidak kondusif bagi kesejahteraan seseorang.

Pengklasifikasian yang dimaksud di atas adalah pengklasifikasian AlGhazali bahwa ilmu itu ada yang ilmu ain dan ilmu kifayah. Ilmu 'ain adalah ilmu yang wajib ditimba dan dicari oleh setiap orang beriman pada setiap situasi dan kondisi. Nurcholis Madjid, misalnya, dan kawan-kawan Paramadina Mulya, menyebut ilmu-ilmu 'ain ini dengan ilmu-ilmu tradisional, seperti fiqh dan ushul fiqh, akidah dan ilmu kalam, tafsir dan ilmu tafsir, hadits dan ilmu hadits, akhlak dan tasawuf, dan sebagainya

- yang banyak diajarkan di pesantren dan madrasah. Sedangkan ilmu kifayah adalah suatu ilmu bilamana salah satu dari sekian komunitas orang beriman di sekitar telah menekuninya, yang lain tidak wajib mempelajarinya. Kerangka konseptual ini pun akhirnya berimplikasi kepada ilmu wajib dan ilmu tidak wajib, ilmu akhirat dan ilmu dunia, ilmu Islam dan ilmu kafir, ilmu Timur dan ilmu Barat, dan seterusnya. 5

Dengan memberikan penekanan yang agak berlebihan pada ilmu-ilmu agama (al-ulum al-diniyah atau al-ulum al-islamiyyah) di dalam tradisi atau sistem pendidikan Islam, maka menempatkan ilmu-ilmu "non-agama" dan "keduniaan" khususnya ilmu-ilmu kealaman dan eksakta - sebagai akar pengembangan sains dan tekhnologi- pada posisi yang marjinal. Supremasi ini pernah dilakukan Al-Ghazali di dalam membangun struktur kurikulum keilmuan Islam, di mana ilmu-ilmu kealaman eksakta berada pada posisi lebih rendah daripada pengetahuan yang diwahyukan. Sikap demikian muncul oleh karena, meminjam istilah Azyumardi Azra dalam Charles Michael Stanton (1994:vii), adanya pandangan bahwa ilmu-ilmu agama merupakan "jalan tol" menuju Tuhan. Sebelum kehancuran aliran Teologi Mu'tazilah pada masa Khalifah Abbasiyah, Al -Ma'mun, (198-218/813-833), ilmu-ilmu kealaman dan eksakta bukan sesuatu yang tidak ada dalam kurikulum madrasah atau $A l$ Jami'ah. Namun dengan runtuhnya aliran Mu'tazilah terjadilah "pemakruhan" - untuk tidak menyatakan "pengharaman"-terhadap ilmu-ilmu "non-agama". Sebelum proklamasi kemerdekaan

5 Imam Tholkhah dan Ahmad Barizi, Membuka Jendela Pendidikan, (Jakarta: Rajawali Press, 2004), h. 24. 
tanggal 17 Agustus 1945, sebagai resistensi atas kolonialisme di Indonesia sebagian dari para ulama dan pemandu pendidikan keagamaan - madrasah dan pesantren- umumnya "mengharamkan" segala sesuatu yang berkolaborasi dengan kaum colonial, seperti bahasa, seni, tradisi, dan tak terkecuali ilmu pengetahuan yang mereka miliki.6

Namun mari kita lihat apa yang dikemukakan Ziaduddin Sardar ketika dia menemukan sebuah artikulasi yang menurutnya terbaik mengenai epistemology ilmu pengetahuan yang diperolehnya dalam kitab Pengetahuan karya AlGhazali. Dalam kitab tersebut Al-Ghazali menganalisis ilmu pengetahuan berdasarkan tiga kriteria:

\section{Sumber}

a. Pengetahuan yang diwahyukan: pengetahuan yang diperoleh oleh para nabi dan rasul

b. Pengetahuan yang tidak diwahyukan: sumber pokok dari ilmu-ilmu ini adalah akal, pengamatan, percobaan, dan akulturasi (penyesuaian).

2. Kewajiban-kewajiban

a. Pengetahuan yang diwajibkan kepada setiap orang (fardhu 'ain), yaitu pengetahuan yang penting sekali untuk keselamatan seseorang, misalnya etika sosial, kesusilaan dan hukum sipil.

b. Pengetahuan yang diwajibkan kepada masyarakat (fardhu kifayah): yaitu pengetahuan yang penting sekali untuk keselamatan seluruh masyarakat, misalnya pertanian, obat-obatan, arsitektur dan tekhnik mesin.

3. Fungsi sosial

a. Ilmu-ilmu yang patut dihargai: yaitu ilmu-ilmu (sains) yang berguna dann tak boleh diabaikan karena aktifitas hidup ini tergantung kepadanya.

b. Ilmu-ilmu yang patut dikutuk: termasuk astrologi, magis, berbagai ilmu perang, tekhnik genetika, terapi aversi, dan studi ilmiah mengenai penyiksaan.7

\footnotetext{
6 Imam Tholkhah dan Ahmad Barizi, Ibid, h. 25.

7 Sardar Zaiduddin, Sains, Tekhnologi, dan Pembangunan di Dunia Islam, Terj.Rahmani Astuti, (Bandung: Penerbit Pustaka, 1989), h.32.
} 
Dari kerangka keilmuan di atas dapat dipahami bahwa Al-Ghazali sebenarnya tidak memisahkan antara agama dan sains sebagai dua buah kultur yang terpisah, tetapi sebagai dua pilar yang memperoleh rasa solidaritasnya yang vital dari keseluruhan kultur manusia. Jadi dalam kerangka ini, pengetahuan dapat bersifat dinamis dan statis. Terdapat perkembangan dalam bentuk-bentuk ilmu pengetahuan (sains) tertentu seiring berkembangnya penalaran akal manusia terhadap alam semesta, sementara terdapat pula kesadaran akan keabadian prinsipil yang diperoleh dari wahyu.

"Setiap manusia akan celaka kecuali orang yang berilmu, dan orang berilmu akan celaka kecuali yang mengamalkan ilmunya, dan orang yang mengamalkan ilmunya pun akan celaka kecuali yang beramal dengan ikhlas," demikian sabda Rasulullah Saw. yang selalu dikutip Al — Ghazali, yang mana Al-Ghazali beranggapan bahwa seseorang harus mempunyai kesadaran yang mendalam mengenai ajaran agamana guna terbina kebahagiaan dunia dan akhirat. Secara pragmatis teologis, sebagaimana dikutip Abuddin Nata (2000:94).8 Al-Ghazali menyarankan supaya ajaran Islam tidak hanya dikuasai secara kognitif, tetapi juga mengimplementasikannya ke dalam perilaku afektif dan psikomotorik seseorang. Inilah yang kemudian disalahartikan oleh sebagian umat Islam, di mana mereka hanya memberi titik berat kepada ilmu-ilmu ukhrawi dan "mengaborsi" ilmu-ilmu duniawi.

Ibnu Khaldun dalam Muqaddimah-nya membagi ilmu ke dalam ilmu-ilmu intelek (al-ulum al- 'aqliyah) dan tradisional (al-ulum al-naqliyah alwadh'iyyah). Yang pertama, al-ulum al - 'aqliyah, adalah ilmu yang diperoleh melalui kemampuan berpikirnya yang merupakan sifat alaminya, meliputi: (1) ilmu logika, (2) ilmu alam (fisika), (3) ilmu metafisika, (4) ilmu matematika yang meliputi:geometri, aritmatika, musika, astronomi. Yang kedua, al-ulum alnaqliyah al-wadh'iyyah, ilmu yang berdasarkan kepada otoritas syariah, yaitu Al-Qur'an dan As-Sunnah, juga ilmu-ilmu yang berhubungan dengan materi tersebut, dalam arti kita dapat memetik manfaat daripadanya seperti (1) ilmu tafsir, (2) ilmu qiraat, (3) ilmu hadits, (4) ilmu ushul fiqh, (5) ilmu fiqh, (6) ilmu kalam, (7) ilmu lughah. Hal yang sama yang dikemukakan oleh

8 Imam Tholkhah dan Ahmad Barizi, Op.Cit, h. 270. 
Al-Ghazali. Kedua kelompok ilmu ini, dalam kacamata Ibnu Khaldun, harus dipelajari oleh manusia secara seimbang untuk pencapaian kesempurnaan dirinya. Tanpa adanya keseimbangan antara keduanya, manusia tidak akan mencapai sesuatu yang diharapkan.9

Dengan demikian, dapat disimpulkan bahwa pemisahan ilmu pengetahuan tidak mendapatkan legitimasi. Pembagian itu hanya persoalan metodologis. Lagipula, bila dilihat dalam perspektif aksiologis, bahwa ilmu dikembangkan di samping untuk ilmu itu sendiri (science for the sake science only), juga adalah bagaimana ilmu itu dikembangkan untuk meningkatkan kemakmuran manusia (science for the sake human progress). Di mana akal seorang individu sebagai penemu dan pengembang sains dan tekhnologi, didukung dengan keluhurannya dalam pemanfaatan sains dan tekhnologi tersebut yang menentukan "the man behind the gun."

Dalam Islam sendiri, Al-Qur'an sebagai kitab rujukan umat Islam sebenarnya tidak mengenal dikotomi. Al-Qur'an justru menginstruksikan kaum beriman untuk senantiasa ber-tafakkur (QS.Ali Imran [3]: 189-190) dan bertasyakkur (QS.An-Nahl [16]: 114). Perintah memikirkan segala ciptaan Tuhan di langit dan di bumi melalui hukum-hukum-Nya di dalam Al-Qur'an mengandung pengertian bahwa sains (science) merupakan jalan untuk mendekati Kebenaran Tuhan. Karena kata fakkara, seringkali diterjemahkan dengan to reflect atau refleksi, dalam bahasa Indonesia kata ini mengandung unsur makna merenung. Perenungan seseorang di atas aras pemikiran seringkali harus diimbangi dengan dzikir, karena ketika pikir tidak bisa bicara akan Kebenaran maka panggilan iman ( $d z i k r)$ mesti tampil memberikan justifikasi ke arah Kebenaran sesungguhnya. Sedangkan tasyakkur, berarti memanfaatkan nikmat dan karunia Tuhan dengan akal modern, sehingga kenikmatan itu bertambah atau mengandung berkah. Dalam istilah modern bersyukur berarti memanfaatkan segenap kemampuan tekhnologi secara maksimal dan positif baik untuk pribadi maupun masyarakat. Dan orang yang mampu mengharmonikan kedua unsur tersebut - tafakkur dan tasyakkur- disebut ulul albab.10

\footnotetext{
9 Abdul Rahman, Pendidikan Integralistik, Menggagas Konsep Manusia dalam Pemikiran Ibnu Khaldun, (Semarang: Walisongo Press, 2009), h.82.

Ahmad Barizi, Pendidikan Integrasi, Akar Tradisi dan Integrasi Keilmuan Pendidikan Islam, (Malang: UIN Maliki Press, 2011), h. 23.
} 
Kesalahan pemahaman umat Islam terhadap konsep Al-Ghazali yang telah disebutkan di atas, bisa jadi karena kekhawatiran umat terhadap pesatnya perkembangan ilmu pengetahuan dan tekhnologi sebagai hasil aplikasi sains yang sudah menerobos dinding-dinding beton kamar-kamar kita melalui TV, internet dan sebagainya, yang menyuguhkan kesenangan bagi kehidupan lahiriah manusia secara luas yang mana perkembangan itu sering diikuti dengan dekadensi moral dan kemerosotan kehidupan beragama, atau seperti dijelaskn oleh Sachiko Murata dalam The Tao of Islam, membawa nafs lebih cenderung menjalin hubungan dengan jasad yang keras, padat serta gelap dan mejauhkannya dari ruh yang lembut dan bercahaya.

Sistem pendidikan sekuler yang diadopsi oleh umat Islam dari Barat yang memberikan tekanan berlebihan terhadap akal rasional, menganggap sepele nilai spiritual dan lebih bersifat antroprosentris daripada teosentris. Ketika Islam mulai terputus hubungannya dari sains dan tekhnologi menjelang akhir abad ke-16, bangsa Eropa dan Amerika secara dinamis mengayunkan langkah ke depan seiring kemajuan sainsnya mulai menjajah dunia secara politik dan intelektual di atas ketidakberdayaan umat Islam.

Dalam menyikapi penjajahan ini, para intelektual muslim terpecah menjadi dua. Kelompok pertama bersikap curiga dan waspada terhadap apapun yang berasal dari Barat yang mereka anggap bertujuan untuk menghancurkan warisan budaya tradisional. Sedangkan kelompok kedua menganggap bahwa sekalipun penjajah, Barat dinilai membawa kemajuan bagi kehidupan umat sehingga mengikuti pola piker Barat dapat dijadikan alternative untuk dijadikan wacana pendidikan. Dan imbasnya system pendidikan di dunia muslim menjadi dualism yang saling berseteru. Perseteruan ini menurut Fazlur Rahman sangat merugikan, sebab mempertentangkan secara dikotomik tradisi dan modernisasi akan menjadikan umat Islam terperangkap pada sikap tradisionalisme yang mengisolasi mereka dari proses dinamika zaman, sehingga menjadikan umat Islam kehilangan peran vitalnya dalam berdialektika dengan perkembangan eksternal. Sebaliknya berlebihan dalam menerima modernisasi akan mengakibatkan umat Islam tercabut dari akar tradisinya. 11 
Dalam mengurai benang kusut dikotomi sistem pendidikan ini, para intelektual muslim telah berusaha mencari solusi-solusi alternatif dengan menggagas upaya "islamisasi" ilmu pengetahuan yang dipelopori oleh tokoh muslim seperti Ismail Raji Al-Faruqi, Naquib Al -Attas dan Sayyid Husein Nasr. Pemikiran yang masih terkesan sporadis dan belum terintegrasi menjadi sebuah pemikiran yang utuh, namun setidaknya menjadi awal dalam pengintegrasian agama dan sains modern yang nantinya seperti yang disebutkan Ahmad Barizi (2011:260): "bukan hanya menciptakan sebuah "proses pencampuan" biasa (islamisasi), melainkan sebagai sebuah "proses pelarutan".,

\section{Islamisasi Sains}

Salah satu upaya oleh pemikir Islam adalah pengintegrasian kembali ilmu umum dan ilmu keislaman. Istilah yang populer adalah Islamisasi.

Menurut Imaduddin Khalil, islamisasi ilmu pengetahuan berarti melakukan suatu aktifitas keilmua seperti mengungkap, mengumpulkan, menghubungkan dan menyebarluaskannya menurut sudut pandang Islam terhadap alam, kehidupan dan manusia. Sedangkan menurut Al-Faruqi, islamisasi ilmu pengetahuan adalah mengislamkan disiplin-disiplin ilmu atau lebih tepat menghasilkan buku-buku pegangan pada level unversitas dengan menuang kembali disiplin-disiplin ilmu modern dengan wawasan (vision) Islam.12

Gagasan islamisasi ilmu pengetahuan pada hakikatnya muncul sebagai respon atas dikotomi antara ilmu agama dan sains yang dimasukkan Barat sekuler dan budaya masyarakat modern ke dunia Islam. Kemajuan yang dicapai sains modern telah membawa pengaruh yang menakjubkan, namun di sisi lain juga membawa dampak yang negatif, karena sains modern (Barat) kering nilai atau terpisah dari nilai agama. Di samping itu islamisasi Ilmu Pengetahuan juga merupakan reaksi atas krisis sistem pendidikan yang dihadapi umat Islam, yakni

12 Yuldelasharmi, makalah berjudul Dikotomi Ilmu Pengetahuan, Akar Tumbuhnya Dikotomi Ilmu dalam Peradaban Islam, dalam buku Sejarah Pendidikan Islam, editor: Samsul Nizar (Jakarta: Kencana, 2007). H.235. 
adanya dualisme sistem pendidikan Islam dan pendidikan modern (sekuler) yang membingungkan umat Islam.13

Gagasan awal islamisasi ilmu pengetahuan muncul pada saat konferensi dunia pertama tentang pendidikan muslim di Makkah, pada 1977 yang diprakarsai oleh King Abdul Aziz University. Ide islamisasi ilmu pengetahuan dilontarkan oleh Ismail Raji al-Faruqi dalam makalahnya "Islamisizing social science" dan syekh Muhammad Naquib al-Attas dalam makalahnya "Preliminary Thoughts on the Nature of knowledge and the Aims of Education". Menurut al-Attas bahwa tantangan terbesar yang dihadapi umat Islam adalah tantangan pengetahuan, bukan bentuk kebodohan, pengetahuan yang disebarkan ke seluruh dunia Islam oleh peradaban Barat. Menurut alFaruqi bahwa sistem pendidikan Islam telah dicetak dalam sebuah Karikatur Barat, sehingga dipandang sebagai inti dari malaise atau penderitaan yang dialami umat. Ia mengkritik sains Barat telah terlepas dari nilai dan harkat manusia dan nilai spiritual dan harkat dengan Tuhan.14

Bagi al-Faruqi, pendekatan yang dipakai adalah dengan jalan menuang kembali seluruh khazanah sains Barat dalam kerangka Islam yang prakteknya tidak lebih dari usaha penulisan kembali buku-buku teks dan berbagai disiplin ilmu dengan wawasan ajaran Islam. Sedang menurut al-Attas adalah dengan jalan pertama-tama sains Barat harus dibersihkan dulu unsur-unsur Islam yang esensial dan konsep-konsep kunci sehingga menghasilkan komposisi yang merangkum pengetahuan inti. Bahkan dewasa ini muncul pendekatan baru yaitu merumuskan landasan filsafat ilmu yang islami sebelum melakukan islamisasi pengetahuan. Sejalan dengan kedua tokoh di atas, Sayyid Husein Nasr menganjurkan visinya tentang islamisasi baru yang dijauhkan dari matrik sekuler dan humanistik (dari sains modern). Ia mengkritik sains Barat, karena menyebabkan kehancuran manusia dan alam. Oleh karena itu, Nasr menganjurkan agar semua aktivitas keilmuan harus tunduk kepada norma agama dan hukum-hukum suci Islam. Sayangnya, Nasr tidak merinci langkah selanjutnya islamisasi sains. Ia cenderung

\footnotetext{
13

M. Zainuddin, Paradigma Pendidikan Terpadu: Menyiapkan Generasi Ulul Albab, (Malang: UIN-Maliki Press, 2008), hlm. 68

14 M. Zainuddin, Ibid, h. 68-69.
} 
menggambarkan prinsip umum dari bangunan sains yaitu agar tidak terpisah dari muatan nilai agama.15

Untuk merealisasikan gagasannya tentang islamisasi ilmu pengetahuan, alFaruqi meletakkan fondasi epistemologinya pada prinsip tauhid yang terdiri dari lima macam kesatuan, yaitu:

1. Keesaan Allah bahwa tidak ada Tuhan selain Allah, yang menguasai dan memelihara alam semesta. Ini berimplikasi bahwa sains bukan hanya menerangkan dan memahami realitas yang terpisah dari Tuhan, tapi sebagai bagian integral dari eksistensi Tuhan.

2. Kesatuan ciptaan bahwa semesta ini baik yang material, psikis, biologi, sosial, maupun estetis adalah merupakan kesatuan yang integral untuk mencapai tujuan tertinggi Tuhan yang menundukkan alam semesta untuk manusia.

3. Kesatuan kebenaran dan pengetahuan, kebenaran bersumber pada realitas, dan realitas bersumber dari satu yaitu Tuhan. Maka, apa yang disampaikan lewat wahyu tidak bertentangan dengan realitas yang ada, karena keduanya diciptakan oleh Tuhan.

4. Kesatuan hidup yang meliputi amanah, khilafah, dan kaffah (komprehensif).

5. Kesatuan manusia yang universal mencakup seluruh umat manusia tanpa terkecuali. Maka, pengembangan sains harus berdasar pada kemaslahatan manusia secara universal.16

Al-Faruqi menegaskan bahwa kelima hal di atas harus menjadi landasan atau fondasi utama dalam upaya pengembangan ilmu dalam Islam. Sehingga perkembangan ilmu itu sesuai dengan maslahat umat. Fondasi ini tentunya tidak akan ditemukan dalam pengembangan ilmu Barat. Tanpa fondasi tersebut, ilmu yang ditawarkan Barat di satu sisi memberi dampak positif, namun di sisi lain, memberi dampak buruk bagi manusia itu sendiri. Terutama menyangkut moral dan keyakinan terhadap Tuhan.

\footnotetext{
15 M. Zainuddin, Ibid, h. 69-70.

16

M. Zainuddin, Ibid, h. 70-71.
} 
Sebagai penggagas utama ide islamisasi ilmu pengetahuan, Al-Faruqi memberikan gambaran tentang bagaimana islamisasi itu dilakukan. Al-Faruqi menetapkan lima program sasaran dari rencana kerja islamisasi ilmu, yaitu: (1) Penguasaan disiplin ilmu modern, (2) Penguasaan khazanah Islam, (3) Menentukan relevansi Islam dengan masing-masing disiplin ilmu modern, (4) Mencari cara untuk melakukan sintesa kreatif antara khazanah Islam dengan ilmu -ilmu modern, (5) Mengarahkan aliran pemikiran Islam ke jalan-jalan yang mencapai pemenuhan pola rancana Allah Swt.17

Wacana tentang islamisasi sains ini mengundang respons yang bermacammacam. A.M Saifuddin misalnya, memberikan respons yang positif terhadap islamisasi sains. Menurutnya islamisasi sains merupakan suatu keharusan bagi kebangkitan umat Islam, karena sentral kemunduran umat Islam dewasa ini adalah keringnya ilmu pengetahuan dan terposisikannya pada posisi yang lebih rendah dari masalah agama, hal ini menurutnya berkonsekuensi pada ignorance bahkan iluminasi terhadap sains.18

Sementara di sisi lain, Hanna Djumhana berpandangan bahwa Islamisasi sains tidak perlu dan tidak bisa dilakukan, sebab antara agama dan sains mempunyai diferensiasi secara epistemologis. Agama bersumber dari keimanan atau wahyu yang bercorak metafisik, sedangkn sains bersumber dari produk akal dan intelektual manusia yang cenderung bercorak imperik rasional. Dengan demikian menurut Hanna, islamisasi ilmu pengetahuan mempinyai konotasi ketergantungan agama dan wahyu pada kebenaran sains. Dia lebih setuju dengan usaha islamisasi saintis. 19

Senada dengan apa yang dipaparkan oleh Hanna Djumhana di atas, ketidaksetujuan yang lain disampaikan oleh Fazlur Rahman. Menurutnya, tidak perlu ada islamisasi ilmu pengetahuan, karena semua ilmu telah tunduk dalam aturan sunnatullah. Yang terpenting

\footnotetext{
17 M. Zainuddin, Ibid, h. 71.

18

Yuldelasharmi, makalah berjudul Dikotomi Ilmu Pengetahuan, Akar Tumbuhnya Dikotomi Ilmu dalam Peradaban Islam, dalam buku Sejarah Pendidikan Islam, editor: Samsul Nizar (Jakarta: Kencana, 2007). H.236.

19

Hanna Djumhana Bustaman, Integrasi Psikologi dengan Islam, (Yogyakarta: Pustaka Pelajar, 1997), h. 33.
} 
adalah menciptakan manusia yang tahu dan mengerti, tentang nilai-nilai Islam dan kemanusiaan, sehingga mampu menggunakan sains secara konstruktif positif.20

Beberapa pemaparan di atas menimbulkan pertanyaan apakah sains sekarang itu islami atau tidak? Para tokoh pemikir islam berbeda pandangan tentang sains itu sendiri. Ada yang beranggapan bahwa sains itu ada yang islami, netral dan ada yang tidak. Yang menyatakan sains sekarang itu tidak islami merujuk kepada krisis peradaban kontemporer. Sedangkan itu, mereka yang berpandangan bahwa sains itu islami karena banyak penemuan-penemuan baru sains bersesuai dengan konsep-konsep Al-Qur'an tentang alam. Oleh karena itu, yang perlu dilakukan bukanlah islamisasi sains, melainkan modernisasi ilmu-ilmu kalam, fikih, dan tasawuf. Kemunduran peradaban Islam menurut penganut pandangan ini bersumber pada ketidakmampuan umat Islam dalam menggali Al-Qur'an secara ilmiah di satu pihak dan kegagalan mengakomodasi tuntutan zaman sesuai dengan kemajuan sains.21

Sementara para cendikiawan sekuralis-modernis seperti Hoodbhoy dan Abdussalam berpendapat bahwa sains itu adalah universal dan secara kultural adalah netral, sehingga ilmu tidak dapat dicerapi dengan sistem nilai manapun. Lantaran itu mereka menghimbau agar cendikiawan muslim tidak menggubris tesis islamisasi.22

Dalam menanggapi perdebatan ini, Armahedi Mahzar beranggapan bahwa sains itu bukan hanya sekumpulan pengetahuan, melainkan suatu proses yang menghasilkannya. Sebagai proses, sains tak dapat dilepaskan dari konteks sosial dan kultural yang selalu berkembang sesuai dengan kemajuan sains sebagai produk dan tekhnologi sebagai apikasi sains.

Oleh karena itu, sains bukanlah suatu produk yang statis yang bisa diwarnai begitu saja oleh pemakainya. Sains Barat modern terus berkembang dan mengalami transformasi sesuai dengan adaptasi sosio-kultural terhadap tekhnologi sebagai aplikasi sains, serta implikasi filosofis penemuan-penemuan teoritik di dalam sains itu sendiri. 
Islamisasi sains adalah kelanjutan logis rasional dari reorientasi paradigma sains yang sedang berjalan sehubungan dengan kritik-kritik eksternal yang mengaitkan dampak-dampak eksternal negative sains dengan paradigma sains modern. 23

\section{Integralisme Islam}

Dalam Islam hubungan antara sains dan agama bukanlah suatu masalah besar. Karena sains hanyalah sebagian dari ilmu atau 'ilm, yang berasal dari kata dasar 'alima yang berarti mengetahui. 'Ain-Lam-Mim merupakan kata yang paling sering, setelah Lam-Lam-Ha dari kata Allah, yang ditulis dalam AlQur'an sebagai kumpulan wahyu Allah Swt. kepada Rasul-Nya yang terakhir, Muhammad Saw.

Rasulullah sendiri dalam banyak hadits menganjurkan untuk menuntut ilmu. Itulah sebabnya seperti kita temukan dalam kemajuan sejarah Islam klasik, generasi-generasi ulama rajin menerjemahkan tulisan-tulisan ilmiah dari berbagai bahasa untuk kemudian disesuaikan dengan ajaran Islam dan dikembangkan lebih lanjut.

Jadi, secara intrinsik tidak ada pertentangan antara sains dan Islam. Sains dalam pengertiannya yang modern adalah pengembangan dari filsafat alam yang merupakan dari filsafat yang menyeluruh dalam khazanah Yunani. Namun filsafat Yunani terlalu deduktif, yang lebih berdasarkan pada pemikiran spekulatif. Karena itu perlu dilengkapi pengamatan empiris sebagaimana diperintahkan dalam Al-Qur'an.

Berdasarkan argumen epistemologi, ilmu pengetahuan antroposentris dinyatakan bersumber dari manusia dengan ciri khas akal (rasio) sedangkan ilmu pengetahuan teosentris dinyatakan bersumber dari Tuhan dengan ciri khas "kewahyuan". Maka terbentuklah pertentangan antara wahyu dan akal.24

Salah satu metode dalam proses pengilmuan Islam yaitu integralisasi. Integralisasi ialah pengintegrasian kekayaan keilmuan manusia dengan wahyu (petunjuk Allah dalam Al-Quran beserta pelaksanaannya dalam

\footnotetext{
23 Armahedi Maizar, Revolusi Integralisme Islam, (Bandung: Mizan), h.218.

24 Kuntowijoyo, Islam sebagai Ilmu: Epistemologi, Metodologi dan Etika, (Yogyakarta, Tiara Wacana,
} 2006), h. 204. 
sunnah Nabi).25 Ilmu integralistik adalah ilmu yang menyatukan (bukan sekedar menggabungkan) wahyu Tuhan dan temuan pikiran manusia. Ilmu-ilmu integralistik tidak akan mengucilkan Tuhan (sekularisme) atau mengucilkan manusia (other worldly asceticisme). Diharapkan bahwa integralisme akan sekaligus menyelesaikan konflik antara sekularisme ekstrem dan agama-agama radikal dalam banyak sektor.26

Armahedi Mahzar, seorang iteknosof dan pengajar di ITB, menyimpulkan bahwa Islam sendiri telah memiliki konsep kesepaduan. Konsepsi kesepaduan dalam Islam telah banyak ditafsirkan oleh pemikir di kalangan muslim sendiri, seperti Ibn Arabi dan Mulla Shadra. Namun sebagai filsafat tradisional Islam, kedua filsafat tersebut dan filsafat Islam tradisional lainnya tidak cukup untuk menampung perkembangan keilmuan saat ini. Dari sinilah kemudian lahir filsafat integralisme atau Al-Hikmah Al-Wahdatiyah.27

Dalam intergralisme Islam terdapat kesatuan hierarkis yang disebut Armahedi Mahzar sebagai integralitas. Integralitas mempunyai dua sumbu yang saling tegak lurus. Sumbu vertikal disebut sebagai dimensi-dimensi internalitas, sedangkan sumbu horizontal disebut sebagai dimensi-dimensi ekstrnal. Internalitas mempunyai lima dimensi, yaitu materialitas, energisitas, informasitas, normativitas, dan originitas yang secara popular dikenal dengan dimensi-dimensi materi, energy, informasi, nilai dan sumber atau yang oleh Imam Al-Ghazali disebut jism, nafs, 'aql, qalb, dan ruh.

Sementara itu, eksternalitas mempunyai dimensi-dimensi yang bermula dari manusia sebagai individualitas atau mikrokosmik, masyarakat sebagai sosialitas atau mesokosmis, alam semesta sebagai naturalitas atau makrokosmis, dan berakhir pada Tuhan sebagai metakosmis. Jadi relitas lebih dipetakan sebagai jala-jala rectangular ketimbang jala-jala sirkular ala holarki Wilberian. Jala-jala integralitas adalah sebuah matriks, bukan sebuah jala atau lingkaran-lingkaran sepusat. 
Tentu saja, jala -jala persegi integralitas dalam integralisme Islam bukan berarti lebih unggul daripada jala -jala lingkaran holarki dalam integralisme universal Wilberian. Yang jelas jal-jala integralitas itu sebenarnya lebih mudah dipahami oleh seorang muslim, soalnya dimensi-dimensi vertical dalam tataran individu bersesuaian dengan tingkat-tingkat kesadaran yang dalam tradisi tasawuf, sebagai implimentasi dari ihsan, diidentifikasi denga jism, nafs, 'aql, qalb, dan ruh individu.

Dimensi horizontal dalam tataran sumber, teridentifikasi dengan keempat rukun iman tentang Allah, malaikat-malaikat, kitab-kitab dan rasul-rasul, sedangkan dimensi-dimensi horizontalitas dalam tataran materi mencerminkan rukun-rukun iman kelima dan keenam, yaitu iman akan hari kiamat dan akhirat, serta iman tentang takdir Ilahi yang dicerminkan oleh perjalanan hidup manusia dari dunia kembali ke haribaan Ilahi di akhirat.

Sementara itu dimensi-dimensi horizontal yang menghubungkan individu dan peradaban melalui lima tahap mencerminkan rukun Islam yang lima sebagai intisari proses islamisasi peradaban yang disebut Armahedi dengan tazkiyah al- madaniyah yang selalu diawali dengan tazkiyah al-nafsi yaitu proses islamisasi individu. Proses ini dimulai dengan tazkiyah al-nafsi yang intinya adalah tauhid dengan mengucapkan kalimat syahadat, diikuti tazkiyah al-jamaati atau islamisasi kelompok yang intinya dicerminkan oleh perintah shalat. Kemudian proses ini diikuti oleh islamisasi masyarakat atau tazkiyah alijtima' $i$ yang intinya dicerminkan oleh perintah shaum. Lalu diikuti pula oleh perintah zakat yang merupakan inti dari islamisasi peradaban global. Berikut tabel tazkiyah al-madaniyah:

\section{Tabel 1: Tazkiyah Al-Madaniyah}

\begin{tabular}{|c|c|c|c|c|c|}
\hline $\begin{array}{c}\text { Arkanul } \\
\text { Islam }\end{array}$ & Syahadat & Shalat & Shaum & Zakat & Haji \\
\hline Tazkiyah & Nafs & Jama'ah & Ijtima'i & Ummah & Madaniyah \\
\hline
\end{tabular}


Sementara itu, dimensi dimensi horizontal dalam integralitas mencerminkan bahwa agama dan, sains dan tekhnologi dan peradaban tidak dapat dipisahkan satu sama lainnya dalam kehidupan seorang muslim. Itulah kesepaduan kehidupan seorang muslim. Terintegrasi dari yang individualukhrawi dengan yang kolektif-duniawi, karena taka ada keterpisahan antara agama pribadi dan budaya masyarakat yang membentuk kesepaduan horizontal. Akan tetapi ini hanyalah satu dimensi kesepaduan.

Ada dimensi kesepaduan yang lain: kesepaduan vertical dari yang materiil ke spiritual. Secara individual itu berarti kesepaduan "ketaksadaran" badan dengan "kepuncaksadaran" ruh melalui "kebawahsadaran" perilaku, "kesadaran" pikiran, dan "keatassadaran" nurani. Dari sudut pandang ini, berate kesepaduan tekhnologi sebagai ekologi buatan dengan Kitab Suci sebagai sumber transcendental melalui nilai-nilai keagamaan, wawasan budaya keilmuan dan kegiatan kelembagaan masyarakat yang mengendalikan tekhnologi itu. Inilah inti integralisme Islam, kesepaduan ganda yang tidak terpisahkan.

Tabel 2: Integritas Wujud

\begin{tabular}{|c|c|c|c|c|}
\hline $\begin{array}{l}\text { Kategori } \\
\text { Integralis }\end{array}$ & $\begin{array}{c}\text { Mikrokosmos } \\
\text { (individualitas) }\end{array}$ & $\begin{array}{l}\text { Mesokosmos } \\
\text { (kolektivitas) } \\
\end{array}$ & $\begin{array}{c}\text { Makrokosmos } \\
\text { (Alam Semesta) }\end{array}$ & $\begin{array}{c}\text { Metakosmos } \\
\text { (Tuhan) }\end{array}$ \\
\hline Sumber (ruh) & $\begin{array}{c}\text { Kepuncaksadaran } \\
\text { (Ruh) }\end{array}$ & $\begin{array}{l}\text { Kitab suci } \\
\text { Al-Qur'an }\end{array}$ & Malaikat & dzatullah \\
\hline $\begin{array}{l}\text { Nilai-nilai } \\
\qquad(q a l b)\end{array}$ & $\begin{array}{c}\text { Keatassadaran } \\
\text { nurani (superego) }\end{array}$ & $\begin{array}{c}\text { Supra- } \\
\text { struktural } \\
\text { Normatif }\end{array}$ & Prinsip alam & Sifatullah \\
\hline Informasi ('aql) & $\begin{array}{c}\text { Keasadaran diri } \\
\text { (ego) }\end{array}$ & $\begin{array}{c}\text { Supra- } \\
\text { Struktural } \\
\text { Kognitif } \\
\end{array}$ & Hukum alam & Amrullah \\
\hline Energy (nafs) & $\begin{array}{c}\text { Kebawahsadaran } \\
\text { (Id) }\end{array}$ & Struktur Sosial & Gejala alam & Sunnatullah \\
\hline Materi (jism) & $\begin{array}{l}\text { Ketaksadaran } \\
\text { (tubuh }\end{array}$ & Basis material & $\begin{array}{c}\text { Benda-benda } \\
\text { alam dunia }\end{array}$ & Khalqillah \\
\hline
\end{tabular}




\section{Paradigma Integrasi Ilmu Masa Depan}

Dewasa ini manusia sedang menghadapi pilihan orientasi hidup yang krusial antara memilih agama dan sains. Ada perbedaan pendapat dari para penentang agama dan pihak agamawan. Para penentang (sekuler), menyatakan bahwa dalam menafsirkan alam tidaklah merupakan keharusan menghubungkannya dengan Tuhan, sebab mereka dapat menafsirkan alam dalam segla fase dan periodenya berdasarkan penemuan modern tanpa menghubungkannya dengan Tuhan. Tuhan bagi mereka adalah pikiran nonesensial. Walaupun ada suatu anggapan seperti ini, namun hampir semua ilmuawan modern beranggapan bahwa segala peristiwa yang terjadi berjalan sesuai dengan law of nature (hukum alam).

Sebagai pandangan-dunia alternative, pandangan-dunia Islam memasukkan kembali relasi kepada Allah dalam bentuk Din Al-Islam sebagai ruh kolektif tubuh umat muslim yang merupakan ummatan wasathan atau umat penengah, umat yang membentuk sebuah al-madinah al-fadhilah atau peradaban utama.

Din Al-Islam menyangkut hubungan manusia secara social kolektif ke Sang Pencipta-nya Yang Esa melalui Syariah (hukum) dan secara personal individual melalui thariqah (metode) yang berdasarkan aqidah (keyakinan). Din Al-Islam mengatur hubungan antara manusia dan masyarakaat melalui tazkiyah al -ijtima'I (penyucian masyarakat), dan hubungan antara manusia dan dirinya melalui tazkiyah al-nafs (penyucian diri) membentuk akhlaq al-karimah (moral mulia) sesosok nafs al-mardhiyah (diri yang diridhai Allah). Inilah komponen teoologis pandangan dunia baru Islam yang mengoreksi ideology sekelarisme global dengan cara melengkapinya dan menyempurnakannya melalui islamisasi peradaban atau tazkiyah al-madaniyah (penyucian peradaban), sebagai kelanjutan tazkiyah al-insaniyah, penyucia manusia, yang merupakan intisati Din Al-Islam.28

Proses tazkiyah al-madaniyah adalah proses islamisasi peradaban terhadap hubungan manusia dengan alam, melalui penyerasiannya ke dalam kesepaduan, keserasian dan keselarasan dengan Din Al -Islam. Tekhnologi adalah bentuk hubungan manusia dengan alam secara 
kolektif. Seni merupakan hubungan manusia dengan alam secara individual dan sains adalah hubungan manusia dengan alam universal.29

Dalam perspektif ini tekhnologi harus diintegrasikan ke dalam tasyakkur (bersyukur) sebagai bagian dari ta'abbud (pengabdian) kita kepada Allah Swt. Begitu juga sains dan seni harus diintegrasikan ke dalam ta'allum (belajar) sebagai bagian dari tasyahud (kesaksian) kita kepada al-Haqq sebagai kebenaran Mutlak.30

Tasyahud-ta'abbud (kesaksian-pengabdian) pada Allah merupakan perwujudan aktif vertical hablun min Allah (hubungan manusia kepada Alla), sementara tazkiyah an-nafs-al ijtima' (penyucian diri dan kolektif) merupakan perwujudannya yang horizontal hablun minannas (hubungan kepada sesama manusia).31 Ketauhidan dan penghambaan secara vertical kepada Allah serta pengabdian kepada sesama inilah yang menjadi tujuan integralisme sains dalam Islam, di mana tercipta kesepaduan hubungan antara alam-manusia-Tuhan.

\section{PENUTUP}

Urgensi pengintegrasian ilmu semakin didesak perkembangan ilmu pada masa modern ini berjalan sangat pesat. Manusia sebagai subjek terus melakukan penemuan-penemuan baru, pada satu sisi semakin memudahkan manusia dalam beraktivitas, namun di sisi lain memberikan dampak negatif. Berkurangnya nilai moralitas manusia itu sendiri menjadi sorotan utama. Sehingga muncul kembali upaya untuk mengkaji ulang hubungan antara "ilmu" dengan agama.

Ide-ide ini tentunya perlu dirumuskan bagaimana model pengintegrasian ilmu tersebut. Sehingga ide ini bisa diimplementasikan lebih lanjut dalam sistem pendidikan dalam rangka mengembangkan ilmu secara integratif. Baik pada lembaga-lembaga pendidikan, maupun sebagai landasan pengembangan keilmuan lainnya. Sehingga melahirkan generasi yang mampu mengharmonikan antara tafakkur dan tasyakkur yang disebut Generasi Ulul Albab. 


\section{DAFTAR RUJUKAN}

Barizi, Ahmad. 2011. Pendidikan Integrasi, Akar Tradisi dan Integrasi Keilmuan Pendidikan Islam. Malang: UIN Maliki Press.

Djumhana, Hanna Bustaman. 1997. Integrasi Psikologi dengan Islam. Yogyakarta: Pustaka Pelajar.

Kuntowijoyo. 2006. Islam sebagai Ilmu: Epistemologi, Metodologi dan Etika. Yogyakarta: Tiara Wacana.

Mahzar, Armahedi. 2004. Revolusi Integralisme Islam. Bandung: Mizan.

Masruri, Hadi dan Imron Rossidy. 2007. Filsafat Sains dalam Al-Qur'an. Malang: UIN Press.

Ma'arif, Syamsul. 2007. Revitalisasi Pendidikan Islam, Yogyakarta: Graha Ilmu.

Nasution, Harun. 1975. Pembaruan dalam Islam. Jakarta: Bulan Bintang.

Sardar, Ziauddin. 1989. Sains, Tekhnologi, dan Pembangunan di Dunia Islam, Terj.Rahmani Astuti. Bandung: Penerbit Pustaka.

Soleh, Khudori. 2004. Wacana Baru Filsafat Islam. Yogyakarta: Pustaka Pelajar.

Tholkhah, Imam dan Ahmad Barizi. 2004. Membuka Jendela Pendidikan. Jakarta: Rajawali Press.

Sardar, Zaiduddin. 1989. Sains, Tekhnologi, dan Pembangunan di Dunia Islam. Terj.Rahmani Astuti, Bandung: Penerbit Pustaka.

Zainuddin, Muhammad. 2008. Paradigma Pendidikan Terpadu: Menyiapkan Generasi Ulul Albab. Malang: UIN-Maliki Press. 